\title{
Physical and mechanical behavior of glulam beams produced with rubberwood treated with preservatives
}

\section{Comportamento físico e mecânico de vigas laminadas coladas produzidas com madeira de seringueira tratada com preservativos}

\author{
Douglas Lamounier Faria ${ }^{* *}$ (D), Thiago Moreira $\operatorname{Cruz}^{1}$ (D), Matheus Cordazzo Dias ${ }^{1}$ (D), Paulo Junio Duarte ${ }^{1}$ (D), \\ Lourival Marin Mendes' ${ }^{1}$, José Benedito Guimarães Junior ${ }^{1}$ (i)
}

'Universidade Federal de Lavras/UFLA, Departamento de Ciências Florestais/DCF, Lavras, MG, Brasil

*Corresponding author: douglas.lamounier@yahoo.com

Received in May 8, 2020 and approved September 21, 2020

\begin{abstract}
This work aimed to evaluate the physical and mechanical behavior of glued laminated timber (GLT) - glulam pieces of Hevea brasiliensis treated with chromed copper arsenate (CCA), chromed copper borate (CCB) and pyrethroid in the production of GLT. The pieces were produced using three wooden laminae with dimensions of $60 \times 20 \times 1200 \mathrm{~mm}$, (width $\times$ thickness $\times$ length), joined with epoxy adhesive under 1.0 MPa pressure for $24 \mathrm{~h}$ at room temperature. The rubberwood had an apparent density of $0.624 \mathrm{~g} \mathrm{~cm}^{-3}$, a value close to that of Eucalyptus grandis wood, a species traditionally used in the manufacture of GLT. Regarding the GLT parts, it was observed that the preservative treatment with CCA and CCB influenced negatively the values of the mechanical properties. For resistance modulus (MOR), a reduction of $75.44 \mathrm{MPa}$ to 62.36 and $58.57 \mathrm{MPa}$ was found for the parts untreated and treated with CCA and CCB, respectively. There was no statistical difference for surface treatment with pyrethroid. The photomicrographs of the glue line showed that the reduction in these values was mainly due to the penetration of preservative solutions into the wood structure (cell lumens and vessels or pores), impairing the anchoring of the adhesive.
\end{abstract}

Index terms: Adhesive wood bonding; static bending; delamination; preservative treatment.

\begin{abstract}
RESUMO
Esse trabalho teve por objetivo avaliar o comportamento físico e mecânico de madeira laminada colada (MLC) de Hevea brasiliensis tratada com arseniato de cobre cromatado (CCA), borato de cobre cromatado (CCB) e piretróide na produção de MLC. As peças foram produzidas com três lâminas com dimensões de $60 \times 20$ × $1200 \mathrm{~mm}$ (largura x espessura x comprimento), unidas com adesivo epóxi sob 1,0 MPa de pressão durante $24 \mathrm{~h}$ à temperatura ambiente. A madeira de seringueira tinha densidade aparente de $0,624 \mathrm{~g} \mathrm{~cm}^{-3}$, valor próximo ao da madeira de Eucalyptus grandis, espécie utilizada tradicionalmente na fabricação de MLC. Em relação às peças de MLC, observou-se que o tratamento preservativo com CCA e CCB influenciou nos valores das propriedades mecânicas. Para o módulo de ruptura (MOR), foi verificado redução de 75,44 MPa para 62,36 e 58,57 MPa para as peças sem tratamento e tratadas com CCA e CCB, respectivamente. Já para o tratamento superficial com piretróide não houve diferenças estatísticas. As fotomicrografias da linha de cola mostraram que a redução desses valores ocorreu sobretudo pela penetração das soluções preservativas na estrutura da madeira (lume celular, vasos ou poros), prejudicando a ancoragem do adesivo.
\end{abstract}

Termos para indexação: Ligação madeira adesivo; flexão estática; delaminação; tratamento preservativo.

\section{INTRODUCTION}

Natural of the Amazon basin, the species Hevea brasiliensis (Willd. ex Adr. De Juss.) Muell. Arg. (Euphorbiaceae), known as rubber tree is the main source for the commercial production of high quality natural rubber. Because it is of tropical origin, this tree grows well in humid regions and has been cultivated in countries in
Southeast Asia for years, especially in Malaysia, Indonesia and Thailand (Lau et al., 2016).

Commercial plantations for latex extraction in Brazil have grown considerably in recent years, and according to the Brazilian Tree Industry - IBÁ (2019), the area of rubber crops in the country went from 159,000 ha in 2010 to 218,307 ha of total area in 2018. As a result of the growing demand for renewable materials, the development 
of products from the rubber tree is essential, considering that after the rubber extraction cycle that lasts from 25 to 40 years in Brazil, the remaining wood of rubber tree is used for products of lesser added value, such as charcoal or firewood for energy purposes.

Based on consolidated experiences in Southeast Asia, rubberwood has good technological characteristics of potential in the forestry industry (Eufrade Junior et al., 2015). In the last decades, this raw material has become important for the manufacture of furniture, due to the attractive coloring and density of the material (Teoh et al., 2011). In the panel segment, rubber tree wood has been used in the production of cement-wood composites (Iwakiri et al., 2017), LVL panels (Faria et al., 2020), particulate panels (Iwakiri et al., 2018; Lamaming et al., 2020) and glued laminated timber (GLT) beams (Nadir et al., 2016; Parra-Serrano et al., 2018; Faria et al., 2019).

The GLT is an engineering product that consists of the juxtaposition of several layers of wood laminae glued with adhesives, forming large and strong structural elements that may be used as beams and columns (Nadir et al., 2016). Obtaining composites with efficient mechanical performance and resistant to environmental actions and xylophagous agents is a challenge, mainly because this material is used for structural uses.

In general, the traditionally commercialized woods do not show resistance to degradation to xylophagous agents, requiring certain treatments for longer duration of the wood (Canadian Wood Council, 2018). In the case of rubberwood; stain, mold and wood decay fungi are real threats to its structural composition. By the high severity of rubber tree decay, there is a need for preservative treatment to prevent infestation by xylophagous organisms, especially in tropical countries with hot and humid climates (Teoh et al., 2011).

Treated wood has a longer lifespan compared to in natura wood, requires less effort related to replacement and has a lower maintenance cost (Vivian et al., 2015). The preservation of the material depends on the addition of toxic substances or repellents, known as wood preservatives, with a focus on increasing the resistance to deterioration and durability (Lepage et al., 2017). In Brazil, the most used treatments are those based on chromed copper arsenate (CCA) and chromed copper borate (CCB) (Vidal et al., 2015; Borges et al., 2018).

This way, guaranteeing uses that present greater added value to the material is essential in the use and profitability of more profitable products in view of the market. Given the above, this work aimed to evaluate the physical and mechanical behavior of glued laminated timber (GLT) - glulam pieces of Hevea brasiliensis treated with chromed copper arsenate (CCA), chromed copper borate CCB and pyrethroid in the production of GLT.

\section{MATERIAL AND METHODS}

\section{Obtainment and preservative treatment of the rubberwood}

Three specimens of 25 year old, higher than 500 mm of diameter breast height (DBH), clone $\mathrm{Pb} 235$, rubber trees (Hevea brasiliensis) were collected from the Campus of the Federal University of Lavras (UFLA), located in Lavras, (altitude: $900 \mathrm{~m}$; latitude: $21^{\circ} 14^{\prime} \mathrm{S}$ and longitude: $\left.45^{\circ} 00^{\prime} \mathrm{W}\right)$ State of Minas Gerais, Brazil. From each tree, logs were obtained from the basal area (length close to $1.30 \mathrm{~m}$ ), which were treated with CCA and CCB within 24 hours after harvesting the trees. The CCA and CCB are water-soluble, fungicide and insecticide products based on chromed copper arsenate and chromed copper borate, respectively, using a prepared solution of $2.5 \%$ of active ingredients.

The sap-displacement method was used during 15 days by radial transpiration. After 20 days in a covered place with environment temperature for the $\mathrm{CCA}$ and $\mathrm{CCB}$ preservative fixation, the logs were sawn in planks. For the treatment based on pyrethroid preservative, the Pentox ${ }^{(\mathrm{TM})}$ (Montana Química S/A, São Paulo, Brazil) was applied on wood by brushing, after sawn and obtainment of the specimens. The boards were conditioned in an environment with temperature of $22 \pm 2{ }^{\circ} \mathrm{C}$ and relative humidity 65 $\pm 5 \%$. Subsequently, the samples were obtained with the dimensions according to established by Brazilian standards until moisture content of $\approx 12 \%$.

To shear strength test, $50 \times 50 \times 64 \mathrm{~mm}$ (width $\mathrm{x}$ thickness $\mathrm{x}$ length) specimen was used, according to Brazilian Standard - NBR 7190, Brazilian Association of Technical Standards - ABNT (1997). To moisture content and apparent density evaluations, $20 \times 30 \times 50 \mathrm{~mm}$ (width $\mathrm{x}$ thickness $\mathrm{x}$ length) specimens were used, according to NBR 7190 (Associação Brasileira de Normas Técnicas ABNT, 1997).

\section{Production of the glulam beams}

From the central boards we obtained laminae with cross-section of $25 \times 70 \mathrm{~mm}$ and length of 1200 $\mathrm{mm}$ which were dried until reaching moisture content of $\approx 12 \%$. Subsequently, the faces were planned to reach the final dimensions of $20 \times 60 \times 1200 \mathrm{~mm}$ (thickness $\mathrm{x}$ width $\mathrm{x}$ length). The pieces were classified by the 
impulse excitation technique with the Sonelastic machine (Sonelastic, ATCP, Brazil). For the glulam production, laminae were classified according to the modulus of elasticity (MOE) value, being the pieces higher than 2000 MPa intended to the faces while the pieces lower than 2000 $\mathrm{MPa}$ were placed in the core.

The glued GLT (glulam) beams were produced with three laminae, producing five untreated beams, five beams treated with CCA, five treated beams with $\mathrm{CCB}$ and five ones treated with pyrethroid, totaling twenty beams glued with adhesive composed by epoxy resin (Tekbond, Brazil), bi-component, in proportion 1:1 of the resin (Bisphenol) to the catalyst (Triethylenetetramine) (Table 1).

\section{Properties of the glulam beams}

After pressing, the beams were conditioned in an environment with temperature of $22 \pm 2{ }^{\circ} \mathrm{C}$ and relative humidity $65 \pm 5 \%$ until reaching the moisture of $\approx 12 \%$. Shear strength tests were performed on the glue line for evaluation of its quality. In total, twelve samples were obtained from the glued laminated timber produced and evaluated according to the American Society for Testing and Materials - ASTM D-905 (American Society for Testing and Materials - ASTM, 2013). Static bending tests were performed according to the ASTM D198 (ASTM, 2015), for determination of the MOE and MOR.

To determine the delamination of specimens extracted from glued laminated beams, six specimens measuring $7.5 \times 6.0 \times 6.0 \mathrm{~cm}$ (length, width $\times$ thickness) were drawn parallel to the fibers, using the methodology described by Lestari et al. (2015). The test was performed by allowing the samples to remain immersed for six hours in water, eighteen hours in a forced air oven at $40 \pm 3{ }^{\circ} \mathrm{C}$, 4 hours under boiling water at $100^{\circ} \mathrm{C}, 1$ hour immersion in water at room temperature and finally 18 hours in an oven at $70 \pm 3{ }^{\circ} \mathrm{C}$.

After the test, the behavior of the glued laminated beams exposed to the exterior was evaluated, evaluating the percentage of delamination, which was obtained on the two top faces of the specimens. In order to verify the percentage, the length of each glue line in which delamination occurred was obtained, and this will be divided by the total length of the glue line, as Equation 1 .

$$
\text { Del }=(\text { DelLength/TotalLength }) * 100
$$

Where: Del is the delamination (\%); DelLength is the length at which delamination occurred $(\mathrm{mm})$; and TotalLength is total length of glue line ( $\mathrm{mm})$.

\section{Wettability analysis}

For wettability analysis, contact angle measurements in the longitudinal surface of the laminae were performed by the sessile drop method, using the Krüss DSA25 instrument and the DSA3 software module (Hamburg, Germany). In this test were used distilled water and epoxy resin.

The drop deposited over the material presented $10-\mu \mathrm{L}$ volume and the measurements were performed every 1 second during 60 seconds. The initial contact angle $(\theta \mathrm{A})$ was registered after 5 seconds and the final contact angle $(\theta \mathrm{A})$ was registered after 60 seconds. For each preservative treatment, 25 measures of $\theta$ A were made, totaling 100 measures.

\section{Study of the wood-adhesive interface}

The study of the wood-adhesive interface was carried out according to the methodology proposed by Albino, Mori and Mendes (2010). Samples were taken from the radial and longitudinal positions of a central cube of $0.5 \times 0.5 \times 0.5 \mathrm{~cm}$ from the glued laminated timber beams. Such cubes were saturated under vacuum condition until they stayed soft to cut. The wooden histological laminae were obtained using a slide microtome (Jung SM 2000). Two laminae were taken from each cube, one in the transversal plane and the other in the longitudinal one of the glued laminated timber beam. The cuts were washed, dehydrated and fixed on permanent laminae with Entellan.

Table 1: Characteristics of adhesive and conditions used for glulam beams production.

\begin{tabular}{ccc}
\hline Characteristic/Condition & Value & \\
\hline Apparent viscosity $\left(25^{\circ} \mathrm{C}\right)$ & Resin: $30000-50000 \mathrm{cP}$ & Proportion 1:1 \\
$\mathrm{pH}$ & Catalyst: $20000-35000 \mathrm{cP}$ & \\
Grammage & 11 & \\
Pressure and clamping time & $1 \mathrm{MPa} ; 24 \mathrm{~h}$ (room temperature) & \\
\hline
\end{tabular}


FARIA, D. L. et al.

Photomicrographs of laminae were obtained using an epifluorescence microscope (Zeiss) connected to the computer and using the Image Pro-Plus 5.1 program. The average thickness of the glue line was obtained along one extreme point of the sample in relation to the other, using the ImageJ software. The glue line of the GLT beams was analyzed by optical microscopy using a SMZ 1500 stereomicroscope (Nikon) and also by scanning electron microscopy (SEM) technique.

The specimens to be evaluated by SEM technique were prepared from the GLT beams, using three specimens per treatment. The specimens were $6 \mathrm{~mm}$ in diameter and $3 \mathrm{~mm}$ thick, with the glue line centered on each specimen. The specimens were covered with a $6 \mathrm{~nm}$ layer of gold in an evaporator and taken to a scanning electron microscope to obtain the electromicrographs of the glue line.

\section{Statistical analysis}

To evaluate the properties of the rubberwood and glued laminated timber beams, the data were submitted to analysis of variance (ANOVA), test $F$ and the Scott-Knott test, both at $p<0.05$. A normality test was performed using the method Shapiro-Wilk. The data was processed using the Sisvar software (Ferreira, 2014).

\section{RESULTS AND DISCUSSION}

\section{Physical properties of rubberwood treated with CCA, CCB and pyrethroid}

The moisture content obtained for the wood was consistent with the local equilibrium humidity, close to $\approx$ $12 \%$ (Figure 1). The results were obtained once that the wood was kept in a room with temperature of $22 \pm 2{ }^{\circ} \mathrm{C}$ and $65 \pm 5 \%$ of relative humidity, presenting hygroscopic equilibrium moisture.

The effects of the wood moisture content on the adhesive bond performance, starts with the amount and absorption rate of the adhesive liquid part. Therefore, the lower the moisture content of the wood is, the higher is the absorption and cure rate and the adhesive solidification (Iwakiri et al., 2005).

Each type of adhesive requires a specific range of moisture content of the wood, in order to promote an adequate adhesion between the pieces of laminated wood. The epoxy adhesive presents better adhesion to the wood with moisture content close to $\approx 12 \%$ (Gemert; Bosch, 1987). The satisfactory results for the mechanical properties may be explained by the good adhesion between adhesive and wood. The use of dried laminations is extremely important for the success of the glulam beams, since high moisture content damages the gluing process and produces checking and other drying defects (Stark et al., 2010).

The moisture content obtained in the present study was below $18 \%$, the maximum value permitted by the NBR 7190 (ABNT, 1997). GLT is normally manufactured using lumber with the moisture content in the range $10-16 \%$. It generally comes with camber or upward deflection. When manufactured with a moisture content of less than $12 \%$ and used under conditions where the moisture content is less than $12 \%$, GLT is practically free from shrinkage (Issa; Kmeid, 2005).

It is observed in Figure 1, that there were no significant statistical differences for apparent density. The wood density may be considered as a good indicator of the wood strength properties, because a higher wood density reflects in a greater quantity of material per volume, offering a greater strength to the material (Braz et al., 2014). Higher density species are more recommended when higher durability and mechanical strength of the structure are desired (Abruzzi et al., 2012).

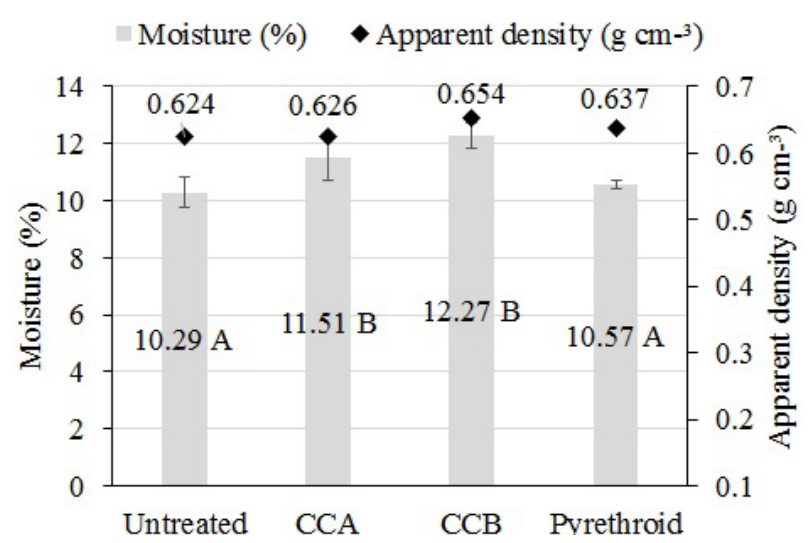

Figure 1: Values obtained for the moisture content and apparent density for the untreated and treated rubberwood. Means with the same letter do not differ (Scott-Knott, $p>0.05$ ).

The density of the wood is also related to its porosity and permeability, which in turn influences the movement of liquid flow through the woody structure (Albuquerque; Latorraca, 2000). Depending on the type of adhesive and the density of the wood, the adhesive can penetrate three to five cells, filling the open cells or covering its internal walls (Sellers Junior, 1994). The literature reports results for apparent density for rubberwood of $0.572 \mathrm{~g} \mathrm{~cm}^{-3}$ 
(Iwakiri et al., 2017) and $0.590 \mathrm{~g} \mathrm{~cm}^{-3}$ (Riyaphan et al., 2015), therefore, the values observed in this work are close to those observed in the literature.

\section{Mechanical characterization of the glulam beams of rubberwood}

The mean values obtained for MOR for glulam timber presented statistical differences for the different preservative treatments (Figure 2). The beams produced with rubberwood treated with $\mathrm{CCA}$ and $\mathrm{CCB}$ presented lower MOR values. Similar in static bending, being lower than those obtained for untreated wood and pyrethroid.

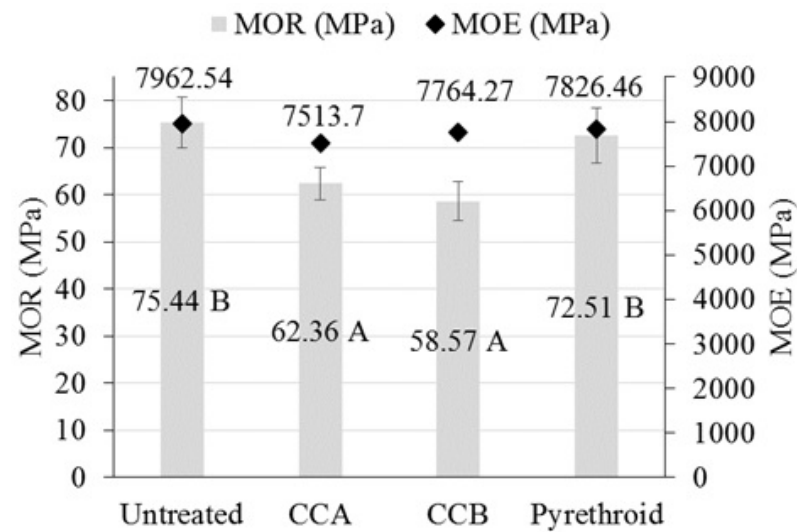

Figure 2: Values obtained for MOE and MOR for the untreated and treated glulam beams made with rubber tree wood in static bending tests. Means with the same letter do not differ (Scott-Knott, $\mathrm{p}>0.05$ ).

The literature reports MOR values ranging from 49.25 to $83.33 \mathrm{MPa}$ for glued laminated beams produced with rubberwood (Nadir; Nagarajan, 2014; Parra-Serrano et al., 2018). The wood treated with CCA and CCB showed the lower values for MOR and this strength loss can reach up to $20 \%$ depending on the product retention and severity of the drying temperature applied as American Wood Protection Association - AWPA (2016).

The effects of water-borne preservative treatments on reduction of strength properties of the wood are directly related to several characteristics of the material and the pre-treatment, treatment, and posttreatment process, as species, mechanical property, chemical or type of chemical, product retention and type of product (Winandy; Barnes, Michell, 1992). On the other hand, in general, the water-borne preservative treatment does not affect the properties of MOE when considering wood under standard conditions (AWPA, 2016). For MOE, the values ranged from 7513.70 to
7962.54 $\mathrm{MPa}$ and there was no statistical difference between the treatments.

The quality of the adhesive bond can be seen in Figures 3 and 4, which show micrographs obtained by the techniques of optical microscopy and scanning electron microscopy (SEM) of GLT (glulam) samples produced with wood without preservative treatment and treated with $\mathrm{CCB}$, respectively.

As shown in Figure 3, the GLT glue line produced with untreated wood was uniform throughout, with constant thickness and absence of spots without the presence of adhesive. In Figure 4, there is a non-constant glue line, with the section in part not joined by the adhesive.

The mean values for wood shear, shear of the glue line of the glued GLT beams and delamination are shown in Table 2. The shear strength of the wood is directly proportional to its density, but depends mainly on the direction in which the stress is applied in relation to the growth rings (Massayuki et al., 2014). The mean values obtained for shear strength of rubber trees with and without preservative treatment ranged from 10.23 to $10.84 \mathrm{MPa}$, with no statistical differences between treatments. Nadir and Nagarajan (2014) when evaluating the behavior of GLT beams using rubberwood, obtained $13.45 \mathrm{MPa}$ of shear strength, while Parra-Serrano et al. (2018) found mean values of $10.63 \mathrm{MPa}$ for the same mechanical property.

It was observed that the rubberwood treated with CCA and CCB showed lower mean values for shear strength on the glue line. Similar behavior was related by Segundinho et al. (2017), evaluating the gluing efficiency with polyurethane adhesive, in which they obtained mean values for shear strength of 12.05 and $8.29 \mathrm{MPa}$ for the untreated and treated wood with CCB, respectively. The low values of shear strength of wood treated with CCA and $\mathrm{CCB}$ may be due to modification of the characteristics of surface of wood with consequent reduction of porosity required for adhesion (Vick, 1999). In this specific case, it may be inferred that the presence of the salts in the treated wood had a negative influence on its stability.

In addition, the low shear strength in the glue line of the wood treated with CCA and CCB may be explained by the interaction of the adhesive in the presence of the preservative. This interaction may be impaired by the chemical adhesion of the preservative to the cell walls, which blocks part of the molecular attraction forces (Bertolini et al., 2014). The shear strength depends on the strength of the adherent materials wood and adhesive, on the stress distribution within the glue line and on the ability of the adhesive to transfer the acting stress into the glue line and thus from one adherent surface to the other (Steiger; Arnold; Risi, 2014). 


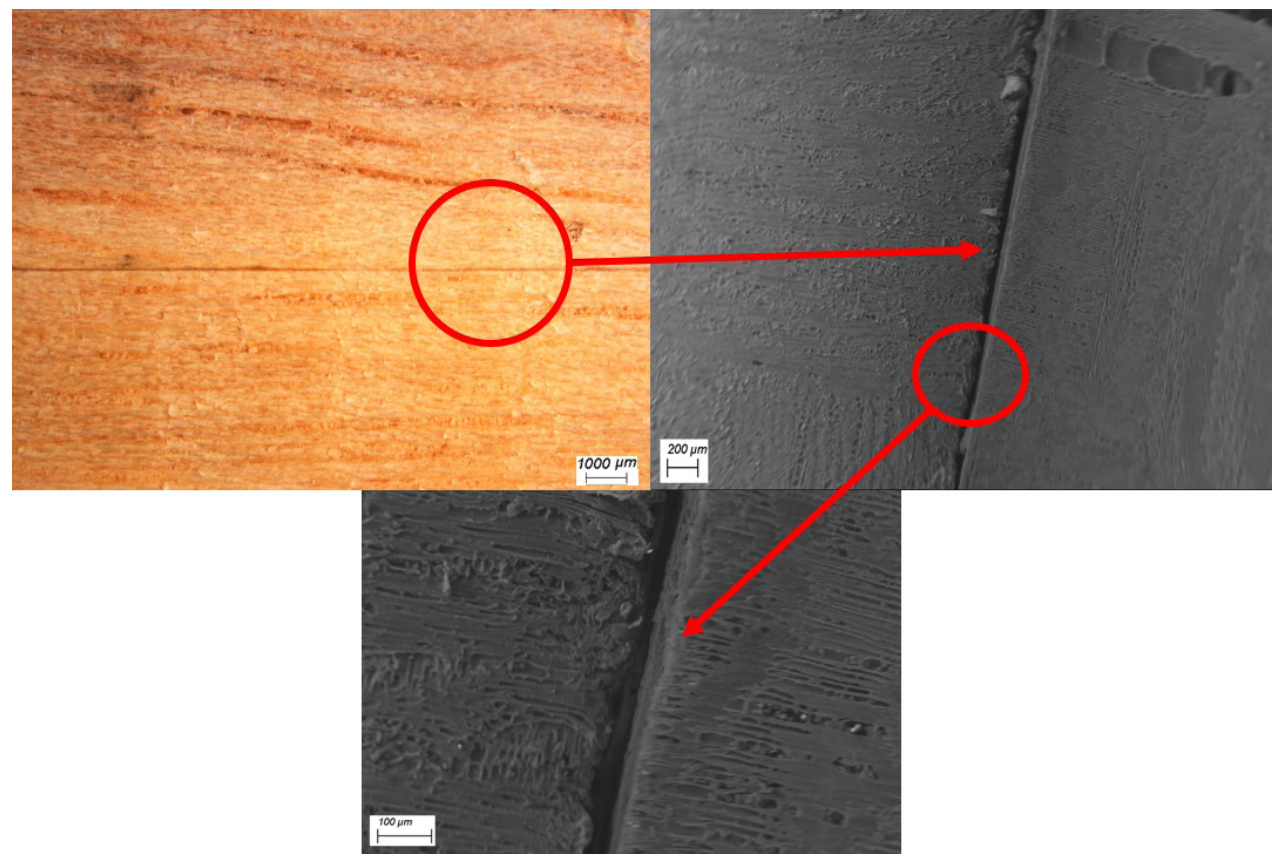

Figure 3: Micrographs of a glulam sample produced with untreated wood. a) Micrograph obtained by optical microscopy; b, c) micrographs obtained by the SEM technique. Red arrow indicates the glue line. Scale bar: $a=$ $1000 \mu \mathrm{m} ; \mathrm{b}=200 \mu \mathrm{m} ; \mathrm{c}=100 \mu \mathrm{m}$.

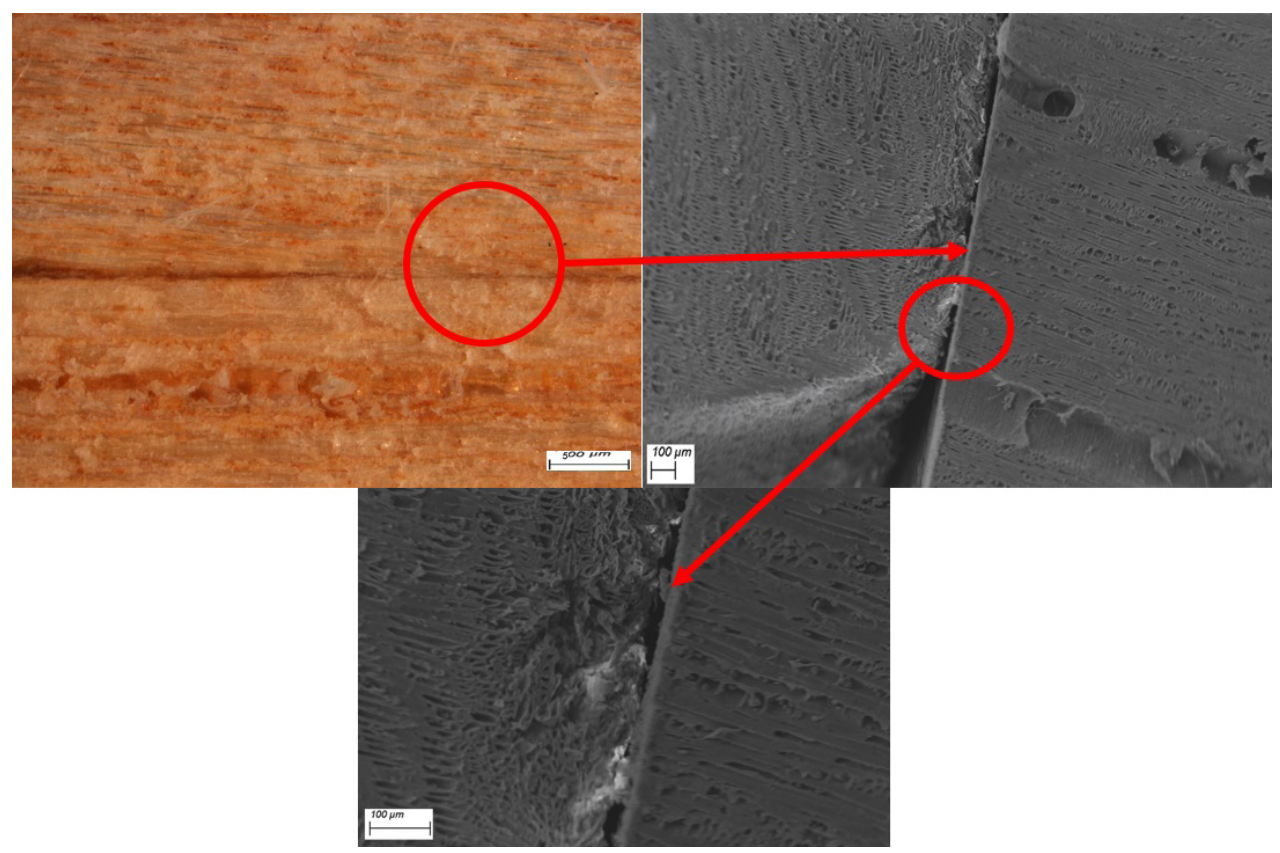

Figure 4: Micrographs of glulam sample produced with CCB-treated wood. a) Micrograph obtained by optical microscopy; b, c) micrographs obtained by the SEM technique. Red arrow indicates the glue line. Scale bar: $a=$ $500 \mu \mathrm{m} ; \mathrm{b}, \mathrm{c}=100 \mu \mathrm{m}$. 
Table 2: Mean values obtained for wood shear, glue line shear and resistance to delamination of GLT beams, for the applied treatments.

\begin{tabular}{cccc}
\hline \multirow{2}{*}{ Treatments } & $\begin{array}{c}\text { Shear strength } \\
\text { (Wood) }\end{array}$ & $\begin{array}{c}\text { Shear strength } \\
\text { (Glulam) }\end{array}$ & Delamination \\
\cline { 2 - 4 } & \multicolumn{3}{c}{$\mathrm{MPa}$} \\
\hline Untreated & $10.84 \mathrm{~A}$ & $10.23 \mathrm{~A}$ & $0 \mathrm{~A}$ \\
CCA & $10.34 \mathrm{~A}$ & $7.11 \mathrm{~B}$ & $70.25 \mathrm{C}$ \\
CCB & $10.42 \mathrm{~A}$ & $6.76 \mathrm{~B}$ & $75.44 \mathrm{C}$ \\
Pyrethroid & $10.23 \mathrm{~A}$ & $9.87 \mathrm{~A}$ & $55.00 \mathrm{~B}$ \\
\hline
\end{tabular}

Means followed by the same letter in the same column do not differ (Scott-Knott, $\mathrm{p}>0.05$ ).

In relation to the test of delamination of the test pieces of glued laminated beams, it was noted by visual verification of the state of the glue lines that the specimens without preservative treatment did not present delamination slits; it was verified that the percentage of delamination was equal to zero. For the GLT beams produced with treated wood, it is observed that the mean delamination values were high, in which the wood treated with CCB presented the highest mean value for delamination, followed by the wood treated with CCA and the wood treated with pyrethroid.

A similar result was observed by Fiorelli and Dias (2005), whose authors obtained 6.64\% delamination for pieces of glued laminated wood produced with epoxy adhesive. ASTM D1101 (ASTM, 2006) and Japanese Agricultural Standard - JAS234 (Japanese Agricultural Standard-JAS, 2003) specifies the percentage delamination not more than $5 \%$ for structural glued laminated timber.

In general, the rubberwood beams under preservative treatment showed inferior results to the material without treatment, these values of delamination and MOR may be explained by the lower anchorage between the adhesive and the wood laminae. The CCA and CCB preservatives used in the composites moved and filled the anatomical elements of the wood, as vases and rays (Figures 5 and 6), causing a negative effect on the adhesion between the wood and the adhesive. Good adhesion is the result of the movement from the adhesive into the wood structure, that is, relative to penetration (Marra, 1992). Still according to Albino, Mori and Mendes (2010) and Singh et al. (2008), the interaction between adhesive and wood occurs mainly through vases and empty spaces, however, studies have proven the effective participation of rays and, to a lesser extent, the axial parenchyma.

In Figure 5 referring to the glue line of GLT pieces produced with preservative treatment (CCB), a glue line thickness slightly higher than the glue line of wood without preservative treatment is noted. This behavior is justified mainly by the preservative material present in the wood structure, in which this material blocked the penetration of the adhesive, thus causing a weaker adhesive bond, since the adhesive consequently did not have access to the interior of the wood to form the anchoring hooks.

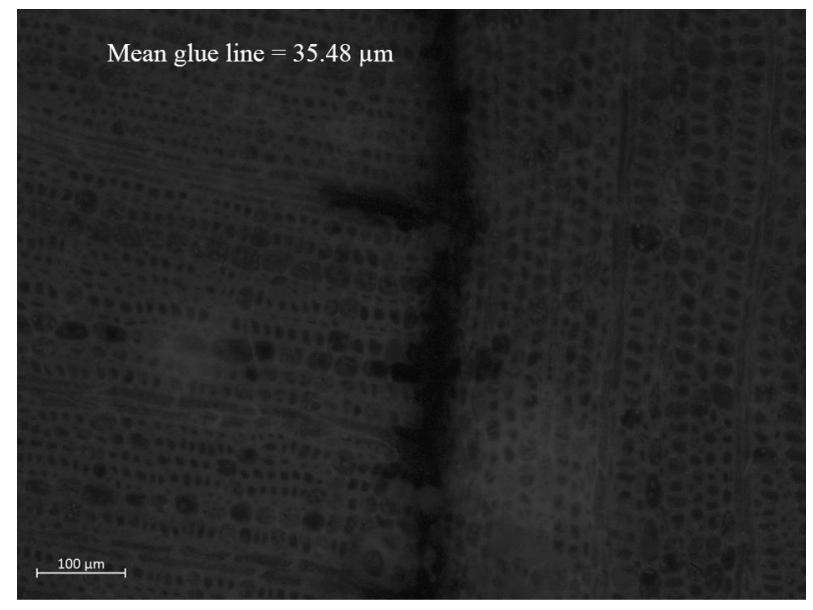

Figure 5: Photomicrograph of the GLT (glulam) sample glue line without preservative treatment.

The higher thickness value of the glue line for the treated wood (Figure 6) may be explained once that the adhesive has impaired penetration in the wood due to the preservative solutions concentrated in the internal cells of the wood. The lower penetration of the adhesive into the wood can also be justified in relation to the contact angle values (Table 3), in which the wood treated with CCA, CCB and pyrethroid obtained the highest mean of contact angle values compared to wood without preservative treatment.

The illustrative images for the contact angles of the epoxy adhesive on the rubberwood with and without preservative treatment, at 5 and 55 seconds after contact with the drop on the wood surface is part of the Figure 7.

In the Table 3, it may be seen that in the measurement time at 5 and 55 seconds, the rubberwood untreated showed the lowest mean contact angle values, differing statistically from the other treatments. The spread of the epoxy drop on the surface of the rubberwood untreated was greater due to the superior permeability of the wood without the preservative solutions, thus facilitating the wetting of the adhesive. It is also observed that wood untreated presented the highest mean contact angle values per second, which is caused by the greater spread of the adhesive on the surface of the wood (Figure 7). 


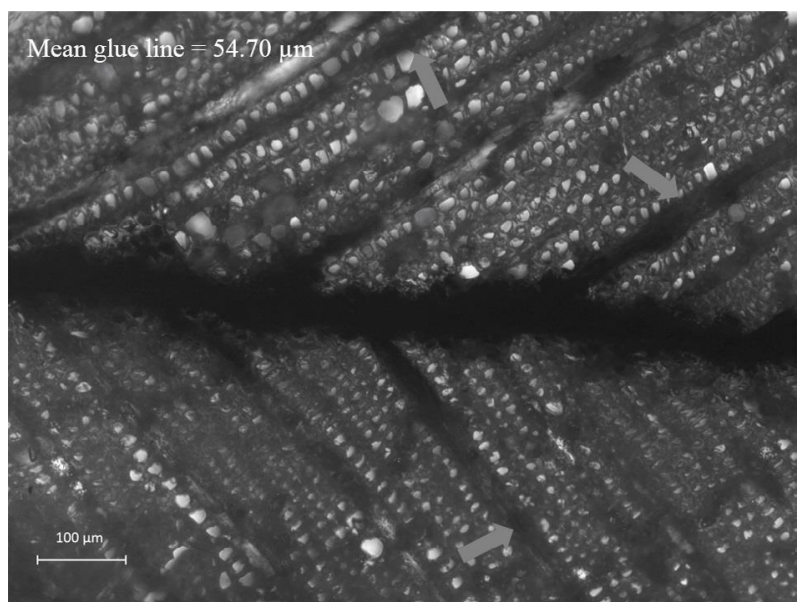

Figure 6: Photomicrograph of the GLT (glulam) sample glue line treated with CCB. Arrow indicates the presence of CCB in the rays of the wood.
Table 3: Contact angle values and degree per second for wood without preservative treatment and treated with CCA, CCB and pyrethroid for each measured time.

\begin{tabular}{ccrc}
\hline Treatments & $\begin{array}{c}\text { Measurement } \\
\text { time }(\mathrm{s})\end{array}$ & $\begin{array}{r}\text { Contact } \\
\text { angle }\left(^{\circ}\right)\end{array}$ & o per second \\
\hline Untreated & 5 & $105.29 \mathrm{~A}$ & 0.434 \\
& 55 & $81.44 \mathrm{~A}$ & \\
$\mathrm{CCA}$ & 5 & $111.17 \mathrm{~B}$ & 0.352 \\
& 55 & $91.82 \mathrm{~B}$ & \\
$\mathrm{CCB}$ & 5 & $114.74 \mathrm{~B}$ & \multirow{2}{*}{0.408} \\
& 55 & $92.33 \mathrm{~B}$ & \\
Pyrethroid & 5 & $111.17 \mathrm{~B}$ & \multirow{2}{*}{0.415} \\
\hline
\end{tabular}

Means followed by the same letter do not differ (Scott-Knott, $p>0.05)$.

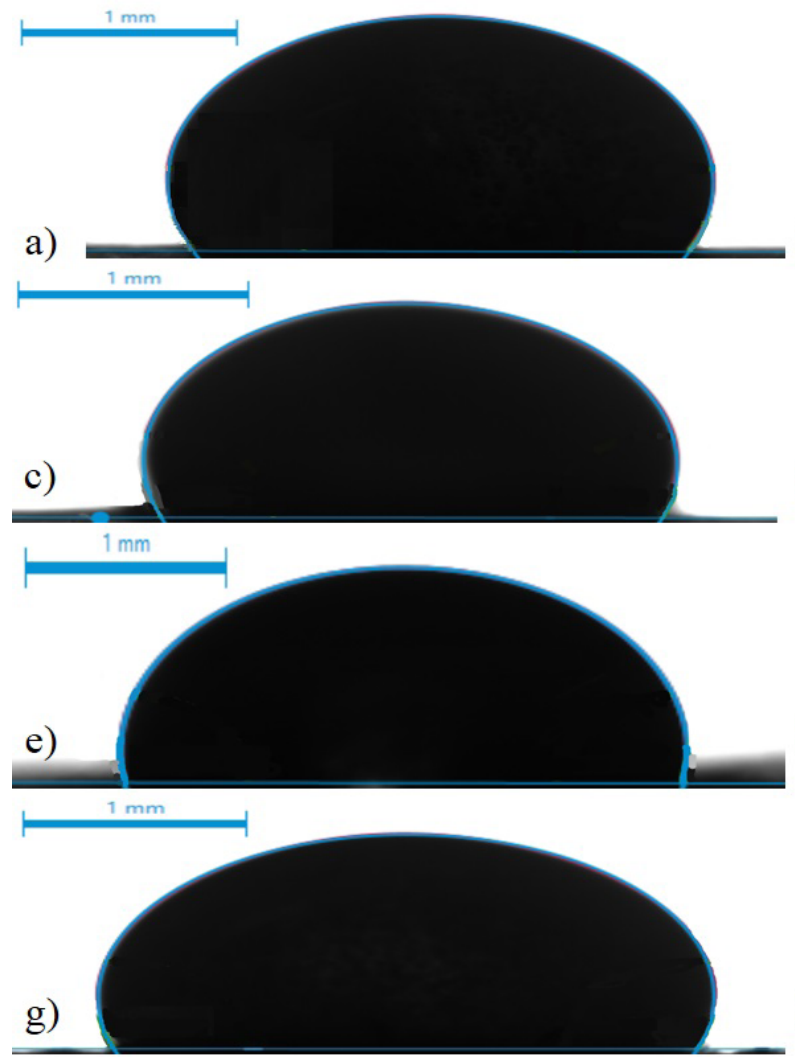

b)

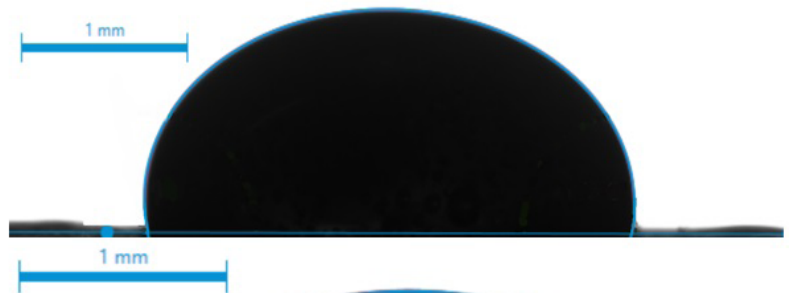

d)

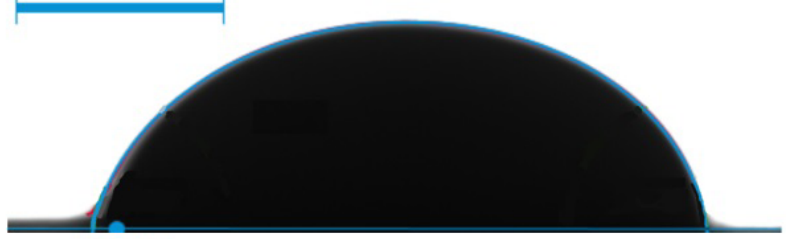

f)

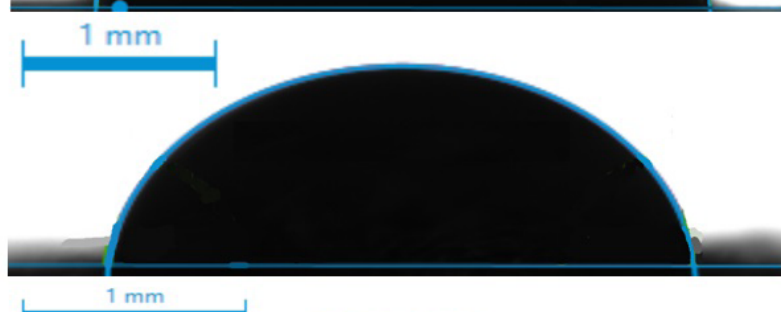

h)

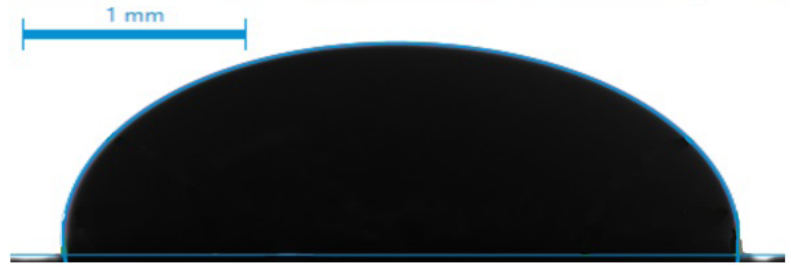

Figure 7: Contact angles. a) Untreated wood at 5 seconds; b) untreated wood at 55 seconds; c) wood treated with CCA at 5 seconds; d) wood treated with CCA at 55 seconds; e) wood treated with CCB at 5 seconds; f) wood treated with CCB at 55 seconds; g) wood treated with pyrethroid at 5 seconds; h) wood treated with pyrethroid at 55 seconds. 
The results of this work are slightly higher than those reported by Amorim et al. (2013), in which the author in a study carried out with surface wettability and roughness of Virola michelli and phenol-formaldehyde adhesive observed mean contact angle values of 82.5 and $81.1^{\circ}$, to 5 and 55 seconds, respectively. As verified by the author and also in this work, initially the contact angle decreased rapidly (spreading phase), however, over time the contact angle slowly reduces and finally reaches equilibrium (diffusion phase) (Laskowska; Kozakiewicz, 2017).

Since rubberwood is susceptible to biodeterioration, the use of this material in structures should be further researched, mainly regarding preservatives that are more efficient and less aggressive to the environment. A possible alternative for the use of these preservative substances on a Nano scale may reduce the negative effect on the anchoring between the adhesive and the wood laminae, resulting in better quality of the glue line.

\section{CONCLUSIONS}

The Hevea brasiliensis wood showed apparent density close to that of Eucalyptus grandis, a species traditionally used in the production of GLT. For mechanical properties, similar values have been reported in the literature. In view of the observed results, it was possible to verify by the photomicrographs obtained by the SEM technique the presence of defects in the glue line for GLT (glulam) pieces produced with wood treated with preservatives. These glue defects were caused by the presence of preservative substances in the wood cells, which consequently reduced the anchoring of the adhesive, reducing the mechanical properties of the GLT pieces. The presence of such preservative substances also impaired the wettability of the adhesive in the wood, in which the spreading of the adhesive on the surface of the laminae under preservative treatment was less in relation to without treatment ones.

\section{REFERENCES}

ABRUZZI, R. C. et al. Relação das propriedades mecânicas e densidade de postes de madeira de eucalipto com seu estado de deterioração. Revista Árvore, 36(6):1173-1181, 2012.

ALBINO, V. C. S.; MORI, F. A.; MENDES, L. M. Estudo da interface madeira-adesivo de juntas coladas com resorcinolformaldeído e madeira de Eucalyptus grandis W. Hill ex Maiden. Scientia Forestalis, 38(87):509-516, 2010.
ALBUQUERQUE, C. E. C.; LATORRACA, J. V. F. Influência das características anatômicas da madeira na penetração e adesão de adesivos. Floresta e Ambiente, 7(1):158-166, 2000.

AMERICAN SOCIETY FOR TESTING MATERIALS. ASTM D - 1101: Standard test methods for integrity of adhesive joints in structural laminated wood products for exterior use. Annual Book of ASTM Standard, West Conshohocken, 2006. Available in: <https://www.astm.org/Standards/D1101. htm>. Access in: April, 30, 2020.

AMERICAN SOCIETY FOR TESTING AND MATERIALS. ASTM D-198: Standard test methods of static tests of lumber in structural sizes. Annual Book of ASTM Standard, West Conshohocken, 2015. Available in: <https://www.astm.org/ Standards/D198.htm>. Access in: April, 30, 2020.

AMERICAN SOCIETY FOR TESTING AND MATERIALS. ASTM D-905: Standard test method for strength properties of adhesive bonds in shear by compression loading. Annual Book of ASTM Standard, West Conshohocken, 2013. Available in: <https://www.astm.org/Standards/D905.htm>. Access in: April, 30, 2020.

AMERICAN WOOD PROTECTION ASSOCIATION. 2016 AWPA Book of Standards, 2016. Available in: <https://www.awpa. com>. Access in: April, 30, 2020.

AMORIM, M. R. S. et al. Molhabilidade e rugosidade superficial de 11 madeiras tropicais amazônicas. Floresta e Ambiente, 20(1):99-109, 2013.

ASSOCIAÇÃO BRASILEIRA DE NORMAS TÉCNICAS. NBR 7190: Projeto de estruturas de madeira. Rio de Janeiro, RJ, 1997. Available in: <https://www. abntcatalogo.com.br/norma. aspx?|D=3395>. Access in: April, 30, 2020.

BERTOLINI, M. S. et al. Painéis de partículas provenientes de rejeitos de Pinus sp. tratado com preservante CCA e resina derivada de biomassa. Revista Árvore, 38(2):339-346, 2014.

BORGES, C. C. et al. Nanoparticles-based wood preservatives: The next generation of wood protection? Cerne, 24(4):397407, 2018.

BRAZ, R. L. et al. Caracterização anatômica, física e química da madeira de clones de Eucalyptus cultivados em áreas sujeitas à ação de ventos. Ciência da Madeira (Brazilian Journal of Wood Science), 5(2):127-137, 2014.

BRAZILIAN TREE INDUSTRY - IBÁ. Annual report 2019. Brasília: IBÁ, 80p. 2019. Available in: <https://iba.org/datafiles/ publicacoes/relatorios/iba-relatorioanual2019.pdf>. Access in: April, 30, 2020. 
CANADIAN WOOD COUNCIL. Durability solutions. Technical Publication, 2018. Available in: <http://cwc.ca/designwith-wood/durability/durability-solutions/>. Access in: April 25, 2020.

EUFRADE JUNIOR, H. J. et al. Potential of rubberwood (Hevea brasiliensis) for structural use after the period of latex extraction: A case study in Brazil. Journal of Wood Science, 61(4):384-390, 2015.

FARIA, D. L. et al. Number of laminae on the mechanical behavior of glued laminated timber (glulam) of Toona ciliata produced with vegetable polyurethane adhesive. Ciência e Agrotecnologia, 43:e014819, 2019.

FARIA, D. L. et al. Studying the grammage in LVL panels glued with castor oil-based polyurethane adhesive: A possible alternative to formaldehyde releasing adhesives. Cerne, 26(1):140-149, 2020.

FERREIRA, D. F. Sisvar: A Guide for its bootstrap procedures in multiple comparisons. Ciência e Agrotecnologia, 38(2):109-112, 2014.

FIORELLI, J.; DIAS, A. A. Avaliação da delaminação em peças de madeira laminada colada reforçadas com fibra de vidro. Revista Matéria, 10(2):241-249, 2005.

GEMERT, D. V.; BOSCH, V. Structural restoration of wooden beams by means of epoxy resin. Materials and Structures, 20(3):165-170, 1987.

ISSA, C. A.; KMEID, Z. Advanced wood engineering: Glulam beams. Construction and Building Materials, 19(2):99106, 2005.

IWAKIRI, S. et al. Adesão e adesivos. In: Painéis de madeira reconstituída. Curitiba: Editora FUPEF, p.13-42, 2005.

IWAKIRI, S. et al. Produção de painéis aglomerados de Hevea brasiliensis (Clone RRIM 600) em mistura com três espécies de Eucalyptus utilizadas pelas indústrias de São Paulo. Scientia Forestalis, 46(117):31-39, 2018.

IWAKIRI, S. et al. Efeitos do tratamento de partículas e aceleradores de endurecimento na produção de painéis cimento-madeira de Hevea brasiliensis. Floresta, 47(3):289-296, 2017.

JAPANESE AGRICULTURAL STANDARD. JAS 234: glued laminated timber. Tokyo, 2003. Available in: <https://trove. nla.gov.au/work/10285527?q\&versionld=11968810>. Access in: April, 30, 2020.
LAMAMING, J. et al. Characterization of rubberwood particleboard made using carboxymethyl starch mixed with polyvinyl alcohol as adhesive. Composites Part B: Engineering, 183:107731, 2020.

LASKOWSKA, A.; KOSAKIEWICZ, P. Surface wettability of wood species from tropical and temperate zones by polar and dispersive liquids. DRVNA Industrija, 68(4):299-306, 2017.

LAU, N. et al. The rubber tree genome shows expansion of gene family associated with rubber biosynthesis. Scientific Reports, 6:28594, 2016.

LEPAGE, E.; SALIS, A. G.; GUEDES, E. C. R. Tecnologia de proteção da madeira. São Paulo: Montana Química S. A, 2017. 225p.

LESTARI, A. S. R, D. et al. Glulam properties of fast-growing species using mahogany tannin adhesive. BioResources, 10(4):7419-7433, 2015.

MARRA, A. A. Technology of wood bonding. Nova York: Van Nostrand Reinhold, 1992. 453p.

MASSAYUKI, M. et al. Shear strength parallel of the wood fiber stress by punching: Proposed test. Revista Ingeniería de Construcción, 29(1):46-60, 2014.

NADIR, Y. et al. Flexural stiffness and strength enhancement of horizontally glued laminated wood beams with GFRP and CFRP composite sheets. Construction and Building Materials, 112:547-555, 2016.

NADIR, Y.; NAGARAJAN, P. The behavior of horizontally glued laminated beams using rubber wood. Construction and Building Materials, 55:398-405, 2014.

PARRA-SERRANO, L. J. et al. Use of Hevea brasiliensis rubberwood for glulam beam production. Floresta e Ambiente, 25(2):1-7, 2018.

RIYAPHAN, J. et al. Variability in chemical and mechanical properties of Pará rubber (Hevea brasiliensis) trees. Science Asia, 41:251-258, 2015.

SEGUNDINHO, P. G. A. et al. Eficiência da colagem de madeira tratada de Eucalyptus cloeziana F. Muell para produção de madeira laminada colada (MLC). Revista Matéria, 22(2):e11808, 2017.

SELLERS JUNIOR, T. Adhesive in the wood industry. In: PIZZI, A.; MITTAL, K. L. Handbook of adhesive technology. New York: Marcel Dekker, p.599-614, cap. 37, 1994. 
SINGH, A. P. et al. Light, confocal and scanning electron microscopy of wood-adhesive interface. Microscopy and Analysis, 22:5-8, 2008.

STARK, N. M. et al. Wood-based composite materials: Panel Products, glued-laminated timber, structural composite Lumber, and wood-nonwood composite materials. In: U.S DEPARTMENT OF AGRICULTURE (Orgs.). Wood handbook: Wood as an engineering material. 100th ed. Madison: United States Department of Agriculture, Forest Service, Forest Products Laboratory, p.252-279, 2010. (General Technical Report FPL-GTR-190).

STEIGER, R.; ARNOLD, M.; RISI, W. Integrity check of structural softwood glue lines: Correspondence between delamination and block shear tests. European Journal of Wood and Wood Products, 72(6):735-748, 2014.

TEOH, Y. P.; DON, M. M.; UJANG, S. Assessment of the properties, utilization, and preservation of rubberwood (Hevea brasiliensis): A case study in Malaysia. Journal of Wood Science, 57:255-266, 2011.
VICK, C. B. Adhesive bonding in wood materials. In: U.S DEPARTMENT OF AGRICULTURE (Orgs.). Wood Handbook: Wood as an engineering material. Madison: United States Department of Agriculture, Forest Service, Forest Products Laboratory, cap. 9, p.1-24, 1999. (General Technical Report FPL-GTR-113).

VIDAL, J. M. et al. Preservação de madeiras no Brasil: Histórico, cenário atual e tendências. Ciência Florestal, 25(1):257271, 2015.

VIVIAN, M. A. et al. Resistência biológica da madeira tratada de Eucalyptus grandis e Eucalyptus cloeziana a fungos apodrecedores em ensaios de laboratório. Ciência Florestal, 25(1):175-183, 2015.

WINANDY, J. E.; BARNES, H. M.; MICHELL, P. H. The effect of initial and post-treatment drying temperature on the tensile strength of CCA-treated Southern Pine. Journal of Materials in Civil Engineering, 4:240251, 1992. 